\title{
PENYULUHAN KEAMANAN PANGAN JAJANAN ANAK SEKOLAH DI SD MIFTAHUL JANNAH BANDAR LAMPUNG
}

\author{
Sri Hidayati*, Dyah Kusumawardani, Fibra Nurainy, Erdi Suroso \\ Jurusan Teknologi Hasil Pertanian, Fakultas Pertanian Unila \\ Universitas Lampung, Jl. Sumantri Brojonegoro No. 1 Bandar Lampung \\ Penulis Korespodensi : srihidayati.unila@gmail.com
}

\begin{abstract}
Abstrak
Makanan jajanan merupakan produk makanan yang dijajakan di pinggir jalan yang secara umum disukai oleh anak sekolah. Untuk meningkatkan pengetahuan mengenai keamanan pangan jajanan tersebut perlu dilakukan usaha untuk memberi pendidikan kepada anak sekolah mengenai keamanan makanan jajanan, bagaimana mengetahui apakah makanan tersebut berbahaya atau tidak dan cara mengenali jenis makanan berbahaya serta memberi pendidikan kepada guru dan penjual sekitar sekolah mengenai bahaya makanan jajanan yang tidak aman bagi kesehatan anak sekolah. Hasil pelatihan menunjukkan bahwa terjadi peningkatan yang cukup signifikan yaitu lebih dari $80 \%$ responden yang semula belum mengetahui mengenai keamanan makanan jajanan menjadi meningkat pengetahuan dan ketrampilannya yang semula hanya $30 \%$ responden yang dapat menjawab kuesioner dan pertanyaan yang diajukan.
\end{abstract}

Kata kunci: keamanan pangan, makanan jajanan, pendidikan

\begin{abstract}
Snack food is a food product sold on the roadside that is generally preferred by school children. To increase knowledge about street food safety, efforts should be made to educate school children about the safety of snacks, how to know whether the food is dangerous or not and how to recognize dangerous food types and educate teachers and sellers around schools about the dangers of snacks not safe for the health of school children. The results of the training showed that there was a significant increase of more than $80 \%$ of respondents who initially did not know about the safety of snacks to be increased their original knowledge and skills only $30 \%$ of respondents were able to answer the questionnaire and the questions asked.
\end{abstract}

Keywords: food security, snacks, education

\section{Pendahuluan}

A. Analisis Situasi

Makanan jajanan merupakan salah satu bagian dalam kehidupan anak sekolah dasar. Kebiasaan jajan dan perilaku mengkonsumsi makanan anak sekolah mempengaruhi kontribusi dan kecukupan energi dan zat gizinya sehingga mempengaruhi status gizi anak. Kebiasaan jajan merupakan istilah untuk mendeskripsikan kebiasaan dan prilaku yang berhubungan dengan makan dan makanan seperti frekuensi makan, jenis makanan, kepercayaan terhadap makanan (pantangan), preferensi terhadap makanan, dan cara pemilihan makanan (Suhardjo, 1989).
Hasil penelitian Ulya (2003) terhadap salah satu SD di Jakarta Timur menunjukkan bahwa kontribusi makanan jajanan terhadap konsumsi sehari siswa berkisar antara $10-20 \%$. Energi dari makanan jajanan memberikan kontribusi sebesar $17.36 \%$, protein sebesar $12.4 \%$, karbohidrat sebesar $15.1 \%$, dan lemak sebesar $21.1 \%$ terhadap konsumsi sehari. Biasanya disekolah tersebut terutama pada jalan menuju arah sekolah banyak terkumpul para penjual makanan jajanan yang menawarkan aneka amakanan jajanan yang menarik selera baik dari segi rasa, aroma dan warna dengan harga yang relatif murah. Di SD Miftahul Jannah yang berlokasi di daerah Rajabasa memiliki lokasi yang cukup strategis yakni dekat 
dengan beberapa lingkungan universitas tetapi memiliki murid dengan beraneka ragam asal dan tingkat ekonomi yang berbeda. Meskipun sekolah mewajibkan anak sekolah membawa bekal dari rumah tetapi karena banyaknya penjual yang menawarkan produk makanan jajanan sehingga menjadi daya tarik tersendiri bagi siswa untuk jajan. Jajanan anak sekolah yang kurang terjamin kesehatannya dapat berpotensi menyebabkan keracunan, gangguan pencernaan dan jika berlangsung lama akan menyebabkan status gizi yang buruk (Suci, 2009). Selain itu, jajanan tidak sehat dapat menyebabkan prestasi anak di sekolah juga terganggu. Pendidikan kesehatan berperan mengubah perilaku kesehatan seseorang sebagai hasil pengalaman belajar (Herijulianti, 2002). Oleh karena itu, perlu diadakan sosialisasi untuk memberikan pengetahuan tambahan kepada orang tua maupun anak-anak mengenai pentingnya memilih jajanan. Oleh sebab itu perlu dilakukan suatu penyuluhan tentang keamanan pangan yang membekali siswa untuk dapat memilih makanan yang sesuai standar yang ditetapkan.

\section{B. Perumusan Masalah}

Makanan jajanan merupakan salah satu bentuk makanan yang sering dijajakan orang dan buka termasuk makanan yang di dalam restoran atau tempat tertutup. Biasanya makanan jajanan dijual dalam bentuk yang menarik agar membuat pembeli menjadi tertarik untuk membeli. Hasil penelitian dari Syafitri et al (2009) di kawasan SD di Jakarta menunjukkan bahwa terdapat 95 jenis makanan jajanan yang terdiri atas makanan camilan/panganan (47 jenis), yang kedua adalah minuman (30 jenis), dan sisanya sebanyak 18 jenis merupakan makanan utama/sepinggan. Makanan jajanan $(77.8 \%)$ tersedia di kantin sekolah dan hanya $22.2 \%$ yang tersedia di luar sekolah (penjaja menetap). Pada makanan jajanan kelompok makanan utama/sepinggan (72.2\%) merupakan makanan jajanan tradisional, hanya $27.8 \%$ yang berupa makanan pabrikan. Contoh makanan utama/sepinggan tradisional yang dijual yaitu bubur ayam, kwetiau, nasi goreng, mie ayam, dan lainnya. Sedangkan untuk makanan utama/sepinggan yang merupakan makanan pabrikan seluruhnya tersedia dalam bentuk mie instant. Makanan jajanan kelompok makanan camilan/ panganan sebagian besar (76.6\%) merupakan makanan pabrikan. Jenis makanan jajanan seperti aneka produk ekstruksi, keripik, biskuit, coklat, permen, kacang, serta produk hasil olahan daging dan ikan. Untuk kelompok minuman, $73.3 \%$ merupakan minuman pabrikan seperti minuman serbuk, air kemasan beraroma, minuman berkarbonasi, minuman jelly, serta susu dan produk olahannya. Minuman tradisional yang tersedia diantaranya adalah jus buah dan aneka minuman es. Hal yang menjadi permasalahan pada produk makanan jajanan adalah kekhawatiran terhadap keamanan pangan dri produk jajanan tersebut. Terjadinya masalah tersebut dapat disebabkan oleh para pedagang yang baik disengaja maupun tidak disengaja mengabaikan kaidahkaidah keamanan pangan. Selain itu, ketidaktahuan konsumen juga menjadi pendukung rentannya keamanan pangan pada makanan jajanan anak sekolah (MJAS). Masalah ini menjadi sangat penting karena konsumsi MPJAS yang tidak aman secara terus menerus akan memberikan dampak negatif bagi kesehatan konsumennya, dalam hal ini ialah anak sekolah. Anak sekolah sangat menyukai pangan jajanan. Para pedagang berupaya untuk memberikan penampilan yang menarik dan rasa yang disenangi anak -anak dengan menambahkan

bahan-bahan tertentu tanpa memedulikan keamanannya (Rina, 2007).

Dampak buruk yang bisa terjadi pada anak karena MJAS yang tidak aman tergantung dari beberapa faktor, yaitu faktor banyaknya jajanan yang dikonsumsi, faktor penanggulangan, dan kondisi tubuh anak. Bila semakin banyak konsumsi MJAS yang tidak aman dan semakin lama penanggulangan diberikan, serta semakin lemah kekebalan dan kondisi tubuh anak, maka semakin serius dampak buruk yang bisa dialami. Perlu diketahui bahwa anak lebih rentan terhadap keracunan pangan dibandingkan orang dewasa sehingga diperlukan usaha untuk memberikan pengetahuan baik kepada anak sekolah, pihak sekolah atau guru maupun pihak penjual makanan sekolah mengenai dampak bahaya ketdak amanan pangan dan bagaimana upaya untuk menguranginya.

Dalam mewujudkan keadaan yang diinginkan sebagaimana telah diuraikan di atas, Tim Pengabdian Kepada masyarakaat Unila memandang penting untuk mengadakan kegiatan pengabdian kepada masyarakat dengan melakukan pembinaan terhadap anak sekolah, guru dan penjual melalui penuluhan dan demonstrasi sehingga diharapkan akan meningkatkan 
pengetahuan mengenai pentingnya keamanan pangan.

\section{Tujuan Kegiatan}

Tujuan pengabdian ini adalah: untuk memberikan pengetahuan tentang pentingnya keamanan pangan, bagaimana memilih, menyediakan bagaimana menidentifikasikan dan cara menghindari produk pangan berbahaya

\section{Manfaat Kegiatan}

Manfaat yang diperoleh dengan adanya kegiatan pengabdian kepada masyarakat ini adalah meningkatkan pengetahun dan kesadaran terhadap pentingnya keamanan pangan

\section{Metode Pengabdian}

\section{A. Metode yang Digunakan}

Sesuai dengan tujuan yang akan ditargetkan pada program pengabdian kepada masyarakat, khususnya anak murid SD, guru dan penjual makanan jajanan, maka metode yang akan dilakukan yaitu:

1. Ceramah dan diskusi

Metode ini diterapkan untuk menyampaikan informasi kepada para sasaran mengenai pentingnya kemanan pangan dan bahayanya jika mengabaikan hal tersebut.

2. Demonstrasi beberapa gambar dan cara untuk mengetahui apakah makanan tersebut sudah tidak aman untuk dikonsumsi.

\section{B. Khalayak Sasaran}

Khalayak sasaran dalam kegiatan pengabdian ini adalah murid SD, guru dan penjual makanan jajanan di SD Miftahul Jannah Bandar Lampung.

\section{Hasil dan Pembahasan}

\section{A. Hasil Kegiatan}

Hasil kegiatan memperlihatakan semangat keingin tahuan yang tinggi dari peserta dengan adanya pertanyaan mengenai keingintahuan mengenai keamanan pangan. Kemuadian dilakukan evaluasi awal, proses dan akhir selama penyuluhan, dimana hasil kegiatan pengabdian ini menunjukkan bahwa terjadi peningkatan pengetahuan pada audiensi. Peningkatan pengetahuan peserta menjadi meningkat, hal ini ditandai dengan kemampuan hasil postest. Sebelum dilakukan proses penyuluhan, hampir $30 \%$ audiens tidak dapat menjawab pertanyaan-pertanyaan yang diajukan oleh penyuluh. Tetapi setelah dilakukan proses penyuluhan, para responden hampir $80 \%$ mampu menjawab pertanyaan dengan soal yang sama dan sudah mampu memahami bagaimana keamanan pangan bagi anak sekolah.

\section{B. Pembahasan}

Proses Evaluasi dilakukan dua kalai yaitu pada awal penyuluhan dan akhir penyuluhan. Pada awal penyuluhan dilakukan dengan cara memberikan test awal menggunakan proses tanya jawab dan menjawab kuesioner yang disediakan kemudian dievaluasi dan tahap terakhir dilakukan evaluasi dengan pertanyaan yang sama seperti pada saat evaluasi awal.. Hasil pengolahan data yang diperoleh dari kuesioner tersebut memperlihatkan bahwa pengetahuan awal para murid SD dan penjual makanan jajanan antara 25-30. Hal ini menunjukkan bahwa pengetahuan mengenai topik keamanan pangan masih rendah. Pada umumnya peserta tidak mengetahui cara untuk mendeteksi ada tidaknya bahan tambahan berbahaya bagi makanan di produk yang mereka makan, kurang mengetahui cara deteksi paling sederhana adanya bahan yang kurang aman dan belum tahu adanya pewarna berbahaya maupubn pemanis sintetis berbahaya serta pengaruhnya terhadap kesehatan. Tetapi setelah dilakukan ceramah, diskusi dan praktik, terjadi peningkatan pengetahun seperti yang diharapkan yaitu mereka memahami apa keamanan pangan, bagaimana memilih makanan jajanan yang baik, bagaimana acara mendetejsi dadanya produk pangan atidak tidak aman, untuk para penjual mereka mengetahui bahan tambahan pangan apa saja yang berbahaya bagi kesehatan serta cara higiena pangan agar tidak tercemar dari kontaminasi mikroba dan fisik. .

Peningkatan pengetahuan peserta setelah diadakan penyuluhan menjadi meningkat yaitu rata-rata lebih dari $80 \%$ sudah mampu menjawab pertanyaan dengan benar, hal tersebut mengindikasikan bahwa manfaat yang diperoleh dan tujuan kegiatan penyuluhan kepada masyarakat dapat dikatakan berhasil. Selain itu tingginya 
ketertarikan peserta penyuluhan terhadap materi yang diajarkan. juga cukup tinggi, hal ini tercermin dari banyaknya pertanyaan dan diskusi yang terjadi selama proses penyuluhan. Sehingga diharapkan hasil tersebut akan memberi perubahan pada sikap yang lebih baik dalam hal bagaimana meningkatkan kesadaran diri terhadap keamanan pangan jajanan agar bisa memilih dan menyediakan makanan jajanan yang sehat, aman dan bergizi di lingkungan sekolah

\section{Kesimpulan}

Sekolah perlu melakukan pengawasan terhadap keamanan pangan jajanan di sekolah tyerutama terkait dengan jenis makanan yang dijual, jenis makanan yang dibeli anak sekolah, kebersihan makanan, ada tidaknya bahan tambahan makanan berbahaya di produk makanan jajanan, nilai gizi makanan jajanan yang dijual, tingkat higinitas atau kebersihan dari penjual maupun pembeli. Dengan mengetahui ciri-ciri makanan jajanan yang tidak sehat dan bahaya dari makanan jajajan yang tidak sehat, diharapkan guru dan orang tua dapat mengajari anak ciri-ciri makanan jajanan yang tidak sehat agar anak tidak membeli makanan jajanan yang tidak sehat. Atau orang tua dapat membawakan bekal buat anaknya, agar makanan yang masuk ke dalam tubuh anak terbukti kebersihan dan kesehatannya

\section{Daftar Pustaka}

Adriani dan Wirjatmadi. 2012. Pengantar Gizi Masyarakat. Jakarta: Penerbit Kencana Prenada Media Group
Herijulianti E. 2002. Pendidikan Kesehatan Gigi. Jakarta: EGC

Mudjajanto,E S. 2006. Keamanan Makanan Jajanan Tradisional. Jakarta: Kompas

Rina. 2007. Persepsi Orang Tua dan Guru Terhadap Keamanan Pangan Jajanan Anak Sekolah Dasar di Kota Bogor. . Skripsi. Institut Pertanian Bogor.

Suci, E.S.T. 2009. Gambaran Perilaku Jajan Murid

Sekolah Dasar di Jakarta. Psikobuana, Jakarta, Vol. 1, No. 1, 29-38.

Suhardjo. 1989. Sosio Budaya Gizi. Departe- men Pendidikan dan Kebudayaan, Di- rektorat Jendral Pendidikan Tinggi Pu- sat Antar Universitas Pangan dan Gizi, Institut Pertanian Bogor, Bogor.

Syafitri Y, Syarief, H, Baliwati, Y.F. 2009. Kebiasaan jajan siswa Sekolah Dasar (studi kasus di SDN Lawanggintung 01 Kota Bogor). Jurnal Gizi dan Pangan, 4(3), 167-175.

Ulya N. 2003. Analisis Deskriptif Pola Jajan dan Kontribusi Zat Gizi Makanan Jajanan Terhadap Konsumsi Sehari dan Status Gi- zi Anak Kelas IV, V, dan VI SD Negeri Cawang 05 Pagi Jakarta Timur Tahun 2003. Skripsi Sarjana Kesehatan Masya- rakat, Fakultas Kesehatan Masyarakat, Universitas Indonesia, Depok.

Widodo, J. 2006. Perilaku Makan Anak Sekolah. Direktorat Bina Gizi Kementrian Kesehatan Republik Indonesia (Diunduh pada tanggal 4 Juni 2016) Diakses dari http://gizi.depkes.go.id/makalah/download/perila ku\%20makan\%20anak\%20sekolah.pdf

Winarno. 1997. Keamanan Pangan. Bogor: Institut Pertanian Bogor www.pom.go.id/mobile/index.php/view/berita/13 9/BAHAN-BERBAHAYA-YANGDILARANG-UNTUK-PANGAN.html 